\title{
Formal Finance and Trade Credit during China's Transition*
}

\author{
Robert Cull \\ World Bank \\ Lixin Colin $\mathrm{Xu}$ \\ World Bank
}

Tian Zhu

China Europe International Business School \&

Hong Kong University of Science and Technology

\begin{abstract}
Using a large panel dataset of Chinese industrial firms, we examine the determinants of access to loans from formal financial intermediaries and extension of trade credit. Poorly performing SOEs were more likely to redistribute credit to firms with less privileged access to loans via trade credit, a pattern consistent with some of the extension of trade credit being involuntary. By contrast, profitable private domestic firms were more likely to extend trade credit than unprofitable ones. Trade credit likely provided a substitute for loans for these private firms' customers that were shut out of formal credit markets. As biases in lending became less severe, the amount of trade credit extended by private firms declined.
\end{abstract}

World Bank Policy Research Working Paper 4204, April 2007

The Policy Research Working Paper Series disseminates the findings of work in progress to encourage the exchange of ideas about development issues. An objective of the series is to get the findings out quickly, even if the presentations are less than fully polished. The papers carry the names of the authors and should be cited accordingly. The findings, interpretations, and conclusions expressed in this paper are entirely those of the authors. They do not necessarily represent the view of the World Bank, its Executive Directors, or the countries they represent. Policy Research Working Papers are available online at http:/lecon.worldbank.org.

\footnotetext{
* We wish to thank Hongbin Cai, Yuyu Chen, Asli Demirguc-Kunt, Liansheng Wu, Li-An Zhou and LongKai Zhao for useful comments and the Research Grants Council of Hong Kong for financial support.
}

Contact information: Robert Cull, The World Bank, 1818 H Street NW, MSN MC3-300, Washington, DC 20433. Phone: (202) 473-4664. Fax: (202) 522-1155. Email: rcull@worldbank.org 


\section{Introduction}

China's growth remains a puzzle. In an economy heavily influenced by state involvement, including the ownership of a substantial share of productive capacity, the private sector has achieved explosive growth. However, the institutions typically associated with private growth, particularly those associated with law and finance, are not well developed by international standards. ${ }^{1}$ Indeed, Allen, Qian, and Qian (2005), hereafter AQQ, point out that low levels of institutional development in China (broadly defined to include courts, property rights and finance) have acted as a brake on growth. Thus, the law-institutions-finance view is better able to account for the sluggish performance of SOEs and the listed sector than the dynamism of the private sector.

This is not to argue that the institutions that support growth of the private sector in other countries are irrelevant for China, or that they will not be important in the future. There is, for example, wide variation across regions in the quality of institutions that helps explain similarly wide variation in private economic activity. Using a detailed survey of enterprises in 18 cities that span all Chinese regions, Cull and $\mathrm{Xu}$ (2005) find that enterprise managers' perceptions about the security of property rights, the risk of expropriation by government officials, the efficiency and reliability of courts, and access to credit all affect profit reinvestment rates, which ultimately support a substantial share of firm growth.

However, the fact remains that for many reasonable cross-country measures of institutional development China lags, and yet has a remarkable growth rate fueled by the private sector. There must, therefore, be mechanisms by which private firms have been able to bypass formal institutions and bring about growth. AQQ (2005) go as far as to argue that: "During the early stages of economic growth, alternative institutions and mechanisms alone can support the growth of firms and the overall economy, as is the

\footnotetext{
${ }^{1}$ See LaPorta, Lopez-de-Slianes, Shleifer and Vishny $(1998,2000)$ on the effects of legal origins on institutions, which in turn affect economic outcomes. Djankov, La Porta, Lopez-de-Silanes, and Shleifer (2003) show that legal origin has implications for the functioning of courts. Acemoglu, Johnson, and Robinson (2001) and Beck, Demirguc-Kunt, and Levine (2003a,b) examine how endowments related to geography and the disease environment affected institutional development, including legal and financial institutions. Engerman and Sokoloff $(2000,2002,2005)$ examine the role of geographic endowments on a broader range of institutions, including schooling and the right to vote. Johnson, McMillan, and Woodruff (2002) and Acemoglu and Johnson (2003) examine the role of contracting and property rights institutions on financial and economic outcomes. A final strand of literature, including Beck, Levine and Loayza (2000a,b), Levine and Zervos (1998), and Rajan and Zingales (1998), establishes a link between financial development and growth. In the Beck et al. papers, legal origin is often used as an instrument to demonstrate that the finance-growth link is causal.
} 
case for China based on our evidence.” (p.82). Based on their study of European transition economies, McMillan and Woodruff (2002) conjecture that formal marketsupporting institutions are needed when competition forces down profit margins and when relational contracting gives way to arms-length contracting, often because products and transactions have become more complex. Ex ante contracting becomes necessary to coordinate buyers and sellers. Such competitive pressures are present and growing in China, and thus the gradual transition from informal to formal market-supporting institutions is likely to be well under way. Therefore, to ascribe all of China's remarkable growth to informal institutions could be an overstatement.

In fact, little is known about whether and how these informal arrangements work and how much economic activity they support in China. Using an extensive, nationally representative database of over 100,000 firms including state-owned enterprises (SOEs), we hope to fill a part of that gap by examining the extension of trade credit, one of the informal mechanisms suggested by AQQ (2005) and McMillan and Woodruff (1999) as being relevant for countries at China's level of institutional development. We test whether Chinese firms have used this channel to bypass or substitute for formal institutions to bring about growth. We can identify the firm's ownership type (state, collective, legal-person, private, or foreign), its reliance on external finance, and its profitability, which enables us to test how access to formal finance affects the extension of trade credit, and how that relationship differs across ownership types.

The use of trade credit is prevalent also in developed market economies. In fact, it is "the single most important source of short-term external finance for firms in the United States” (Petersen and Rajan, 1997). The finance literature on trade credit has mostly focused on the issue of why trade credit is used in inter-firm transactions when specialized financial intermediaries such as banks can provide finance. Most theories attribute the use of trade credit to information or other advantages that suppliers have over financial institutions in providing credit to their own customers. ${ }^{2}$ A number of empirical studies (Petersen and Rajan, 1997; Ng, Smith and Smith, 1999) have tried to test these theories by assessing the determinants of trade credit.

More recently, there is a new literature on the role of trade credit as an informal financial institution in developing and transitional economies where formal financing

\footnotetext{
${ }^{2}$ See Petersen and Rajan (1997) for a summary of theories of trade credit and a test of these theories. For more recent theoretical models, see Biais and Gollier (1997)and Burkart and Ellingsen (2004).
} 
channels are underdeveloped. McMillan and Woodruff (1999) study the determinants of the prevalent use of trade credit among private firms in Vietnam, finding that trade credit is more likely to be extended by a supplier when the duration of the relationship with the customer is longer, the customer has fewer alternative sources of supply, or the customer is identified through a business network. Coricelli (1996) argues that private trade credit markets played a key role in Poland's economic transition. In cross country studies, Fisman and Love (2003) find that in countries with relatively weak financial institutions, firms in industries that rely heavily on trade credit have higher growth rates; and Demirguc-Kunt and Maksimovic (2001) find trade credit to be more prevalent in countries with poorer legal systems.

In China, it is not so much the lack of a formal financial system but rather its institutional bias in favor of state-owned enterprises (SOEs) that could give rise to trade credit use among viable firms with restricted or no access to credit from state-owned banks. China therefore offers an opportunity to study trade credit in a state-dominated banking environment notorious for misallocating credit (Lardy, 1998; Cull and Xu, 2003).

Our data only allow us to examine the determinants of the supply of trade credit, because they do not have information on recipients of trade credit. Using a small survey data set, Ge and Qiu (2005) find that non-state-owned firms receive more trade credit than state-owned firms, and are more likely to use that funding for investment than for transactional purposes. Thus, the patterns of trade credit extension that we document are likely to be supportive of productive activities. Moreover, the least profitable SOEs in our sample were most likely to redistribute bank loans via trade credit, which could be consistent with improvement in the overall allocation of credit. However, the relatively modest amount of total trade credit extended and its decline late in the period indicate that this channel cannot explain a large share of the recent growth. Other mechanisms, formal and informal, must also be playing a role.

\section{A Simple Model of Trade Credit Extension}

The key relationships in our analysis are between bank loans received, trade credit extended, and profitability. We illustrate the trade-offs faced by a firm in deciding to extend trade credit using a simple, reduced-form model. A firm receives loans from 
formal financial intermediaries totaling $B$ which it can allocate to its own investment projects or to extending trade credit to its customers. We assume that the average return on its own investment projects is declining in the number of projects that it pursues, because it pursues its best opportunities first and because it has limited capacity to monitor projects. The payoff to those projects is:

$$
r_{f}\left(K_{f}\right) * K_{f}
$$

where $K_{f}$ is the amount of loans invested in the firm's own projects and $r_{f}\left(K_{f}\right)$ is the average return on those projects, which is declining in $K_{f}$. The remainder of the firm's loans is used to extend trade credit to the firm's customers, who have difficulty in accessing formal finance. Under these arrangements, the firm provides goods or services to a customer with an agreement to receive payment (typically higher than the price the customer would pay if it had not received trade credit) in the future. ${ }^{3}$ Here we use a reduced-form representation of the benefit of extending trade credit, and denote the firm's payoff to a portfolio of trade credit as follows:

$$
r_{s}\left(K_{s}\right) * K_{s}
$$

where $K_{s}$ is the amount of formal loans redistributed to customers as trade credit and $r_{s}\left(K_{s}\right)$ is the average return on its trade credit portfolio, which, we assume, is declining in $K_{s}$. This would occur when the firm enters into trade credit arrangements with its most creditworthy customers first.

The firm's maximization problem is simply:

$$
\begin{gathered}
\operatorname{Max} \prod_{k_{f}}=r_{f}\left(K_{f}\right)^{*} K_{f}+r_{s}\left(K_{s}\right)^{*} K_{s} \\
\text { Subject to: } K_{f}+K_{s}=\mathrm{B}
\end{gathered}
$$

For the purpose of this model, we assume that $r_{f}\left(K_{f}\right)$ and $r_{s}\left(K_{s}\right)$ are linear:

$$
r_{f}\left(K_{f}\right)=\alpha_{f}-\beta_{f} K_{f} \text { and } r_{s}\left(K_{s}\right)=\alpha_{s}-\beta_{s} K_{s}
$$

The first order condition is:

$$
\frac{\partial \Pi}{\partial K_{f}}=\alpha_{f}-2 \beta_{f} K_{f}-\alpha_{s}-2 \beta_{s} K_{f}+2 \mathrm{~B} \beta_{s}=0
$$

Resulting in an equilibrium level for $K_{f}$ :

\footnotetext{
3 These are in effect short-term business loans made by suppliers, often to expand their market and customer base. Suppliers can also track repayment through repeated interactions, thus resolving informational asymmetries about the creditworthiness of their customers that formal financial intermediaries can not.
} 


$$
K_{f}^{*}=\frac{\alpha_{f}-\alpha_{s}+2 B \beta_{s}}{2\left(\beta_{f}+\beta_{s}\right)}
$$

To motivate the empirical tests that follow, we are most interested in how access to loans affects $K_{f}^{*}$. That comparative static result is given by:

$$
\frac{\delta K_{f}^{*}}{\partial B}=\frac{\beta_{s}}{\beta_{f}+\beta_{s}} .
$$

Similarly, we have

$$
\frac{\delta K_{s}^{*}}{\partial B}=\frac{\beta_{f}}{\beta_{f}+\beta_{s}} .
$$

As the firm receives more formal loans, it allocates those funds based on the (declining) slope of the returns to its own projects versus the slope of the returns associated with extending trade credit. If the firm's network of customers tends not to be creditworthy, $\beta_{s}$ will be large, and those new funds will result in relatively more investment in its own projects (i.e., a larger $K_{f}^{*}$ relative to $K_{s}^{*}$ ). If the firm's own investment prospects are poor, $\beta_{f}$ will be large, resulting in relatively more extension of trade credit.

As we demonstrate below, unprofitable SOEs in our sample tended to receive more loans than others, reflecting the institutional bias of the state-owned banking system. In the context of this simple illustration, their low profitability also reflects relatively poor investment opportunities, and thus a relatively large $\beta_{f}$. Unprofitable SOEs thus had both poor investment opportunities and relatively abundant credit from banks or other formal financial intermediaries. We would therefore expect them to be more likely to extend trade credit to their customers. Provided the returns to extending trade credit were not too low, redistribution of formal loans by SOEs to their customers might have resulted in a more efficient allocation of credit.

Private domestic firms tended to receive fewer formal loans than SOEs and bailouts from state banks were less likely. We would therefore expect that the only reason that these firms would have an incentive to extend credit is for the reasons typically suggested in the literature - to stabilize, improve, and expand their customer base, and to redistribute relatively cheap loans (at a profit) based on superior information about their customers' ability to repay. Profitable private firms were likely in a better position to 
secure loans for these purposes, or their profits themselves could be used to underwrite trade credit. Profitability might also have been an indication that they could attract a high-quality portfolio of customers. In addition, private firms have stronger incentives to monitor the repayment of trade credit and better incentives to screen "good" clients. For all these reasons, we might expect that profitable private firms would have extended more trade credit than others.

\section{Data}

Our data are drawn from the annual accounting reports filed by industrial firms with the National Bureau of Statistics (NBS), and thus the firms in the database tend to be large and medium-sized. All industrial SOEs are included, along with all other firms with more than 5 million Yuan of sales. ${ }^{4}$ The data are for 1998 to 2003; for each year after 1998 the sample contains information from over 100,000 firms (Table 1). ${ }^{5}$ These firms represent about half of the value added of Chinese industrial firms, and twenty to twentyfive percent of national GDP.

We can identify five different types of firm ownership: state, collective, legal person, domestic private, and foreign. Collective firms are distinct from state-owned in that they are either owned by township-village governments or collectively by the employees. Legal-person share is a mixture of ownership by state legal persons and private legal persons, and based on our conversation with Chinese accounting experts, state legal persons likely account for the majority of legal person-owned firms. ${ }^{6} \mathrm{We}$ classify firms according to their largest ownership type. Therefore, if the state holds forty percent of a firm's shares, while domestic private and foreign interests each hold thirty percent, the firm is classified as state-owned. Table 2 shows that the share of the sample comprised by SOEs declined from $33 \%$ to $16 \%$, that of collective firms from $29 \%$ to

\footnotetext{
${ }^{4}$ However, the threshold of 5 million Yuan is not strictly enforced in the survey so that we do observe some firms with smaller figures of sales.

${ }^{5}$ The sample size in 1998 is half that of the later years because we use lagged variables in the regressions. Because data were not available for 1996 or 1997, the lagged values for most of the 1998 variables are for 1995, a year in which data were available for a much smaller number of firms. For variables related to size, we assume a smooth growing trend, and use the imputed 1997 value as the lagged value for 1998. As a robustness check we dropped the 1998 data from our analysis and the main results remained intact. Given our interest in changes in the relationships between receipt of loans, firm profitability, and the extension of trade credit over time, we have opted to keep the 1998 data to estimate our base results.

${ }^{6}$ Legal persons represent a form of corporate ownership. These corporations are legal entities which, while being owned collectively by a number of natural persons, exist completely separately from them. Under many legal systems, this separation gives the corporation powers that other legal entities lack.
} 
$13 \%$, that of legal person-owned firms increased from $13 \%$ to $21 \%$, that of domestic private firms from $13 \%$ to $34 \%$, and that of foreign firms from $12 \%$ to $16 \%$. This period thus witnessed a significant change in ownership of firms, though in any given year a substantial number of firms of each ownership type can be found. We also control for year dummies to capture the case of macro fluctuations in interest rates.

The breadth of the sample is its key advantage, though that breadth comes at a minor cost in terms of the depth of financial information. For example, we have data on the amount of accounts receivable but not accounts payable. As noted, however, an examination of the credit extended by suppliers of goods and services to their customers can shed light on the motivations of the providers, and on how trade credit extension is related to access to formal sources of finance. In the Chinese case, the key source of external funding is loans from banks or other formal financial intermediaries such as trust companies and credit cooperatives. However, the NBS dataset does not provide information on the quantity of loans that a firm receives. We therefore follow the example of other authors that have used these data such as Cai, Liu, and Xiao (2005), and construct a proxy for the use of loans from formal financial intermediaries equal to interest payments divided by total sales. In China, most interest rates are fixed or float within a rather narrow band and thus interest payments provide information about the stock of pending loans. One might be concerned that the ratio of interest payments to assets would be misleadingly low for firms that default. However, credit tends to be rolled over and thus defaults are rare. In addition, we include profitability in all of the trade credit regressions that follow, which should help control for a firm's ability to repay its loans. It is also useful to point out that interest payments covers interest expenses, processing fees from banks, finance companies (including trust and investment companies), and credit cooperatives, most of which are state-owned. In principle interest payments may also include informal debt (such as from underground loan sharks). However, such informal loan payments should be very small in our sample, which consists of state-owned enterprises that have relatively good access to bank finance, and non-state firms that exceed sales of 5 million yuan. These large non-state firms should also have better access to formal finance than small private firms. For simplicity, we shall view interest payments over sales as a proxy for a firm's access to credit from formal financial intermediaries, most notably banks. 
There are some notable differences between ownership types with regard to formal finance, trade credit extended, and profitability (Table 3). On average, stateowned firms enjoy substantially more access to formal finance: the ratio of interest payments to sales is $6.2 \%$ for SOEs. In contrast, this ratio is $3.2 \%$ for legal person-owned firms, $2.9 \%$ for collective firms, $2.2 \%$ for domestic private firms, and 1.9\% for foreign firms. The low access to formal finance for foreign firms could be because the demand for external finance is lower for those firms due to better access to internal finance (i.e., greater profitability). The amount of trade credit extended ranges from $18 \%$ of total sales for the average domestic private firm to $36.5 \%$ for the typical SOE. In general, trade credit extension is positively related to state ownership as well as to firm size.

We use return on sales $(R O S)$ calculated as profit over sales to measure profitability. ${ }^{7}$ Disparities in average $R O S$ are also wide, ranging from $-0.5 \%$ for SOEs to $13.5 \%$ for domestic private firms. SOEs are therefore the ownership category that suffers the most financial stress. The less formal sector, including collective and domestic private firms, is the most profitable. Sandwiched in between are legal person-owned and foreign firms. On average, an SOE in our sample employs about three times as many workers as a private domestic firm or collective, and about twice as many workers as a legal person-owned or foreign-owned firm. Despite employing more workers, SOEs generate lower average sales than foreign firms (86 versus 105 million Yuan per year). The typical SOE is 26 years old, substantially older than the typical collective (15 years), legal person-owned firms (12), private domestic firm (11), or foreign firm (7). Thus, the basic picture that emerges from our summary statistics is that SOEs are older, larger, less profitable and have better access to loans than other types of firms. Legal person- and collectively-owned firms, which are likely to have some relationship with the government, also tend to be older and receive more credit than private and foreign firms.

Table 4 displays the time paths of our key variables. ROS trends upward, from $6 \%$ in 1998 to $11 \%$ in 2003 . The ratio of interest payments to sales declines steadily over the sample period. This is consistent with the lowering of interest rates that occurred during the period and hence does not necessarily imply the tightening of credit supply.

\footnotetext{
${ }^{7}$ We compute return on sales from items found in the system of national accounts as: ROS= (Gross value of output - Cost of intermediate inputs - Finance charges - Wages - Current period depreciation) / Total Sales. Another alternative would have been to use firms' reports of their gross profits. However, Cai, Liu, and Xiao (2005) point out and provide evidence that firm owners and managers often hide profits in the self-reported figures.
} 
The ratio of trade credit to sales trends downward, suggesting that the use of trade credit became less important over time.

Table 5 shows the correlation between formal credit and trade credit (as a share of total sales). Firms of all ownership types show a positive correlation, which may imply some redistribution from bank credit to trade credit. SOEs and legal person-owned firms exhibit the highest correlation coefficients (0.31 and 0.34 , respectively), followed by collective and private firms (0.28), and foreign firms at 0.18 . The relatively weak link for foreign firms might not be surprising: trade credit relationships need time to foster, and foreign firms tend to be much younger than other ownership types (Table 3).

\section{Empirics}

Our primary goal is to examine which types of firms are more likely to extend trade credit, which we do via the following regression:

$$
\begin{aligned}
\text { TRADE CREDIT } & =\alpha_{i}+\beta_{1} \text { OWNERSHIP }_{i t}+\beta_{2} \text { PROFITABILITY }_{i t-1}+ \\
& \beta_{3} \text { OWNERSHIP }_{i t} \times \text { BANK }_{i t-1}+ \\
& \beta_{4} \text { OWNERSHIP }_{i t} \times \text { PROFITABILITY }_{i t-1} \times \text { BANK }_{i t-1}+ \\
& \beta_{5} X_{i t}+\varepsilon_{i t}
\end{aligned}
$$

TRADE CREDIT is the amount of accounts receivable relative to total sales for firm $i$ in year $t . \alpha$ is a firm-specific intercept. OWNERSHIP represents a vector of dummy variables for the ownership types described above. In the results that follow, state ownership is the omitted category. We also control for PROFITABILITY (ROS), calculated as described above. We lag profitability one year to help address simultaneity problems. The crux of our analysis is the relation between trade credit and formal credit. The redistribution view of trade credit holds that firms with better access to credit redistribute some of the credit to less advantaged (but creditworthy) firms in the form of trade credit (Coricelli, 1994; Petersen and Rajan, 1997; Love, Preve and Sarria-Allende, 2006). The extent of redistribution from formal credit to trade credit could depend on the type of ownership. For example, SOEs that have privileged access to formal credit but few growth or investment opportunities may be more able and willing to engage in onlending to their customers. In contrast, private firms may be credit constrained relative to their growth opportunities, and thus less willing or able to redistribute what little credit 
they have to their customers. In the regression, therefore, we interact the ownership variables with our proxy for formal finance, $B A N K$, defined as interest payments divided by total sales. Again, to avoid simultaneity problem, we lag $B A N K$ one year.

In some specifications, we interact the ownership dummy variables with lagged profitability and formal finance. We include this triple interaction term to test whether the redistribution effect depends on profitability (Biais and Gollier, 1997). For the reasons discussed earlier, we expect that unprofitable SOEs might redistribute the most credit because of privileged access to loans and relatively few productive investment opportunities. Below, we also explore the possibility that some of the trade credit extended by unprofitable SOEs is involuntary. For private firms, trade credit represents an alternative informal delivery channel for their customers that are creditworthy but shut off from formal sources of finance. We expect that profitable private firms would be best positioned to assist their customers in this way, in part because their profits provide a source of investable resources in addition to the loans that they receive.

Finally, $X$ represents additional control variables that might affect the amount of trade credit that a firm extends. The first is firm age, which we expect to be positively related to extension of trade credit (Petersen and Rajan, 1997). In their examination of relational contracting in Vietnam, McMillan and Woodruff (1999) find that longer duration in a trading relationship is associated with larger amounts of trade credit. Presumably, older firms are more likely to have established trust with their customers. We also include firm size measured as once-lagged total sales because larger firms tend to produce intermediate goods, whose clients tend to be small private firms facing credit constraints. Moreover, firm size may directly improve the ability to offer trade credit. Finally, we include the Herfindahl index for each firm's industry because Fisman and Raturi (2004) find that monopoly power is negatively correlated with the provision of trade credit. They hypothesize that firms with market power present holdup problems ex post that deter borrowers from investing in establishing the creditworthiness necessary to sustain these trading relationships. The Herfindahl index is measured at the four-digit industry-year level.

Note that we have controlled for the firm fixed effects, which allows us to control for unobserved time-invariant firm heterogeneity. One important element of firm heterogeneity is the price of trade credit. Trade credit usually is associated with an 
implicit interest rate for delayed payment. Such interest rates tend to be firm-specific and time-invariant (or driven by underlying macroeconomic trends). Controlling for firm fixed effects and year effects should thus allow us to hold constant the implicit price of trade credit.

To get a more complete picture of the efficiency of formal and informal finance, it is also necessary to understand how the determinants of access to loans vary across types of firms. In so doing, we also hope to shed light on which types of firms are in a better position to extend trade credit. Previous studies of China have found that loss-making SOEs receive a disproportionate share of bank finance (Cull and $\mathrm{Xu}, 2003$ ). We test whether that same relationship holds for our dataset, which covers a slightly later period than that used in other studies and includes many more firms. We therefore run the following regression to describe access to formal finance:

$$
\begin{aligned}
\text { BANK }_{i t}=\alpha_{i}+ & \beta_{1} \text { OWNERSHIP }_{i t}+\beta_{2} \text { PROFITABILITY }_{i t-1}+ \\
\beta_{3} \text { OWNERSHIP }_{i t} & \times \text { PROFITABILITY }_{i t-1}+\beta_{4} X_{i t}+\varepsilon_{i t}
\end{aligned}
$$

To mitigate problems stemming from reverse causality (i.e., from bank finance to profitability), profitability is once-lagged. Because we also control for firm fixed effects, we are using within-firm variation to investigate the relationship between changes in firm performance and changes in the firm's access to formal finance.

\section{Results}

\section{a. Access to Formal Finance}

We discuss our regressions in reverse order, starting with equation 2. The negative, significant coefficient for lagged $R O S$ in Table 6, column 1, confirms previous findings that less profitable firms tend to receive more loans than others. In that sense, the allocation of credit appears to be inefficient. Controlling for profitability, SOEs receive the most formal credit, followed by collective and legal-person firms, and then by domestic private and foreign firms. Thus the formal state-owned financial system in China shows an institutional bias in favor of SOEs and against private enterprises.

To test whether the negative relationship between profitability and formal finance is driven by state banks lending more, voluntarily or otherwise, to underperforming firms, in column 2 we re-run the specification for the sub-sample of more profitable firms, that 
is, for firm-years with profitability above the median level (0.104). We find that the negative relationship is no longer statistically significant at the 5 percent level. Moreover, the magnitude of the coefficient for lagged $R O S$ is much reduced, from -0.008 to -0.001 . Relatively inefficient firms therefore receive more formal credit when they make less profit (or make greater losses); relatively efficient firms do not however receive more formal credit as their profits increase. ${ }^{8}$ In that sense, the financial system provides soft budget constraints for inefficient firms.

We suspect that the above relationships between profitability and formal credit vary across ownership types. In column 3, we interact ownership types with profitability. Except for domestic private firms, the interaction with lagged $R O S$ is negative and significant at the one-percent level. Moreover, the negative coefficient for SOEs is at least twice as large (in absolute value) as those for other ownership types. For domestic private firms, the correlation is positive though insignificant, with a t-value of 1.61. In column (4), we again use the more profitable sub-sample, and find that the negative relationships between profitability and formal credit access for ownership types other than domestic private firms are driven by the less profitable firms. That is, the interaction with profitability is not significant for any ownership type. The results from columns (3) and (4) together suggest that China's banking system allocates more credit to underperforming SOEs than they deserve. These results are similar to findings from another transition economy, Poland, by Coricelli (1996).

To test whether there were changes in the way formal finance was allocated as China's transition progressed, in columns (5) and (6) we allow the ownership-specific link between lagged profitability and bank finance to change for the second half of our six year sample period, i.e., the post-2000 period. Table 6 suggests that the allocation of formal credit became less biased, as shown by the positive significant coefficients for the post-2000 interactions across ownership types. For the pre-2001 period, firms of all ownership types have a negative correlation between lagged $R O S$ and formal finance, with domestic private firms having the weakest link among all. Interestingly, foreign firms with lower $R O S$ also obtained more formal finance in this period. Thus there is some evidence that foreign firms also enjoyed subsidies from the banking system in the earlier period. This is consistent with Huang (2003), which presents evidence that local

\footnotetext{
${ }^{8}$ Of course, more profitable firms might have sufficient internal resources that they do not need or want to borrow from banks.
} 
governments offered preferential treatment to foreign investors to compete for foreign direct investment. Again, however, the summary statistics indicate that foreign firms borrowed substantially less than other firm types.

After 2000, only SOEs still have a negative correlation between profitability and loans, but with a much lower magnitude. (The sum of the coefficients of ROS*State and ROS*State*post-2000 is -0.009.) For collective and foreign firms, the link disappears completely. For legal-person-owned firms, the link becomes positive but small (0.001, which is the sum of two coefficients -0.011 and 0.012). However, for domestic private firms, the link is now positive and significant. This pattern implies that budget constraints were hardened and the allocation of formal credit became more efficient in the second half of the sample period.

The main conclusion from the formal finance regressions is that relatively unprofitable SOEs received disproportionately more credit than other firms throughout the period, in line with our expectation that SOEs faced soft budget constraints. The relationship between lagged profitability and formal credit was also negative and significant for all other firm types prior to 2001, though smaller in magnitude than that for SOEs. From 2001 onward there is evidence of a more rational allocation of formal credit, as indicated by the stronger positive relationship between formal finance and ROS for all types of firms, including a significant positive correlation for domestic private firms.

\section{b. Extension of Trade Credit}

We now explore how the extension of trade credit depends on firm characteristics and access to formal finance. The regression results are reported in Table 7. As expected, in all regressions SOEs and older firms extend more trade credit relative to their sales than other firms. In contrast to other studies (e.g., Petersen and Rajan, 1997), smaller firms extend more trade credit as a share of sales. This could be because the customers of small firms may be even smaller and need trade finance, or because smaller firms tend to know more about their customers and have more ability and incentive to collect receivables, and hence are more willing to extend trade credit.

In column 1, we control for lagged profitability and interact the ownership type dummies with the lagged formal finance variable. We thus allow the redistribution from 
formal credit to trade credit to differ by ownership type. The coefficients for formal finance received by SOEs, collectives, and legal person-owned firms are positive and significant. By contrast, the coefficients for foreign and domestic private firms are not statistically significant and negative for domestic private firms. Consistent with our model, these results suggest that enterprises with relatively better access to formal sources of credit offer more trade credit to their customers per unit of bank credit.

The negative relationship between lagged profitability and trade credit in Table 7 is somewhat puzzling. Petersen and Rajan (1997) also find in their sample of small U.S. firms that, conditioning on other variables, more profitable firms offer less trade credit. But presumably, if trade credit is an efficiency enhancing informal financing mechanism, we would expect that more profitable firms extend more trade credit. Petersen and Rajan (1997) suggest that firms in trouble may use the extension of trade credit to try to maintain their sales, and that some of the trade credit extended by financially distressed firms may be involuntary. In our case, the negative relationship may also be driven by the fact that less profitable firms, particularly SOEs, have relatively more formal credit and can afford to extend more trade credit. A third possibility is that more profitable firms have more growth opportunities, but because they do not get proportionately more formal finance (Table 6) they may be credit constrained relative to their growth potential, and hence offering trade credit is more costly to them.

To test these possibilities, in column 2 we use the sub-sample of more profitable firms (ROS above median) and re-run the regression. The negative relationship between ROS and trade credit extension remains for the more profitable firms, which indicates that the result for the full sample was not mainly due to involuntary trade credit or easier access to bank credit for unprofitable SOEs. We therefore prefer the third interpretation above, that more profitable Chinese firms face more binding credit constraints relative to their investment opportunities and hence extend less trade credit. Another possibility is that the customers of the most profitable firms have less need of trade finance, either because they themselves are also profitable or because they have access to formal sources of finance.

For the relatively profitable sub-sample, the tendency for some ownership types to redistribute loans via trade credit is much different than it was for the full sample. The positive redistribution effect for SOEs (as well as legal person-owned firms) becomes 
insignificant, whereas domestic private firms now exhibit a strong positive effect. In other words, the positive redistribution effect for SOEs is driven by less profitable SOEs. By contrast, column 2 indicates that it is the relatively profitable firms that drive the positive association between formal credit and extension of trade credit among the private domestic owners.

A more direct test of whether private domestic firms are more likely to extend trade credit at higher profitability levels comes from adding a triple interaction term that multiplies the ownership dummy variables by profitability and formal finance (columns 3 and 4). The triple interaction term is large, positive, and highly significant for private domestic firms, insignificant for all other ownership types. When we restrict ourselves to the sub-sample of relatively profitable firms in column 4, the triple interaction for private domestic firms is no longer significant, but the simple interaction between private domestic ownership and formal credit is positive and highly significant. Therefore, private domestic firms in the relatively profitable sub-sample all tend to redistribute a high share of their loans as trade credit, an effect that does not change as profitability improves. ${ }^{9}$ Taken together, regressions 3 and 4 indicate that extension of trade credit is more prevalent among private domestic firms with above-average profitability, as we hypothesized. Because credit constraints are more binding for private firms, their total level of investable resources is low when their profit is low; at higher profitability levels, our results suggest they are willing and able to redistribute some of their credit to their customers.

By contrast, our evidence indicates that SOEs are less credit constrained than private firms, and in fact face soft budget constraints. In Section 2, we speculated that less profitable SOEs receive more formal credit than their growth opportunities warrant, and hence could afford to extend more trade credit per unit of formal credit than more profitable SOEs that have more growth opportunities. The regressions in this section are consistent with that conjecture. Moreover, Ge and Qiu (2005) find that non-state-owned firms receive more trade credit than state-owned firms, and are more likely to use that

\footnotetext{
${ }^{9}$ The lagged ROS variable is, however, negative and significant in column 4 . This again points to the possibility that among the most profitable firms, higher ROS may be associated with more opportunities for growth. Being more financially constrained relative to their financing needs than other firms, the most profitable might find credit redistribution less appealing than firms at lower profitability levels.
} 
funding for investment purposes. It is therefore conceivable that the trade credit extended by relatively unprofitable SOEs could result in an improved allocation of loanable funds.

We are, however, reluctant to draw that conclusion. If the accounts receivable of a less profitable SOE are not new credits voluntarily extended but rather reflect delinquent payments by its customers, then that SOE may seek to borrow more money from banks to cover the shortfall. In that case, we would also expect a positive correlation between formal credit and trade credit. Although in the trade credit extension regressions we have allowed for firm fixed effects and also regressed contemporaneous trade credit on lagged bank credit, there is still a possibility that the relationship between trade credit and bank credit runs from the former to the latter or for them to be simultaneously determined. For instance, an SOE may have a large stock of accumulated arrears that require fresh infusions of bank loans over multiple years.

Chinese SOEs may be especially vulnerable to the default risk associated with trade credit for two reasons. First, SOEs do not have good incentives to screen trade credit recipients, and second, SOEs do not go after accounts receivable as doggedly as other firms. Corruption by SOE managers or their sales people exacerbates these two problems. Furthermore, when an SOE faces financial trouble due to financial arrears, they are more likely to be saved by the state banks than other firm types. For all these reasons, the reverse causal relation from trade credit to formal credit would be most likely for SOEs.

To check the possibility of reverse causality, we re-run the credit access regression as follows:

$$
\begin{aligned}
\text { BANK }_{i t}=\alpha_{i}+ & \beta_{1} \text { OWNERSHIP }_{i t}+\beta_{2} \text { PROFITABILITY }_{i t-1}+ \\
& \beta_{3} \text { OWNERSHIP }_{i t} \times \text { TRADE CREDIT }_{i t-1}+\beta_{4} X_{i t}+\varepsilon_{i t}
\end{aligned}
$$

Again, since soft budget constraints are more likely to be faced by relatively unprofitable firms, we also re-run equation (3) on the profitable sub-sample. In Table 8, column 1, lagged trade credit is positively associated with formal credit, consistent with the conjecture that firms that extend more trade credit-some of which is likely to reflect financial arrears - seek more loans to keep themselves afloat. In column 2, that link is a bit weaker for the profitable sub-sample. When we interact trade credit with the ownership dummies in column 3, we find no significant link for private firms, suggesting 
that state banks or other financial intermediaries do not subsidize them in cases of trade credit default. By contrast, SOEs tend to receive significantly more formal credit when they have extended more trade credit. When we restrict ourselves to the profitable subsample in column 4, however, the reverse link between trade credit and formal credit is no longer significant at the five percent level for either SOEs or private firms, and the differences across most firm ownership types are no longer significant.

Returning to the trade credit extension regressions in Table 7 for a moment, our preferred interpretation is that the positive redistribution from formal credit to trade credit for less profitable SOEs arises because much of the trade credit that they extend is involuntary, which results in more bank loans to these firms. State banks are apparently less likely to subsidize profitable SOEs or other types of firms in this way.

In Table 9, we allow the relationship between formal credit and trade credit to differ across two periods. For 1998-2000, we find positive redistribution effects from loans received to trade credit extended for firms of all ownership types. The effect for the post-2000 period is not much different for state, collective and legal person-owned firms, but it goes down sharply for private and foreign firms. In fact, these firms actually extend less trade credit when they have more formal credit, though the net effect of the pre- and post-2000 coefficients is close to zero.

In the 1998-2000 period, the redistribution effect for collective, domestic private and foreign firms increases with profitability, suggesting that when these firms had more money, they were willing to redistribute more credit. For the post-2000 period, we still observe more loan redistribution via trade credit for private firms that have higher profitability. That is, the coefficient on the Bank*ROS*post-2000 dummy is not significant, and thus not significantly different from that for the 1998-2000 period. For collective firms, the post-2000 profitability interaction is negative and significant, negating the positive profitability interaction for the early period. Foreign firms evince a similar pattern, except that the post-2000 profitability interaction is not significant. The net effect of the two profitability interactions (pre and post-2000) for foreign firms is, however, close to zero. Thus, the tendency for profitable collective and foreign firms to redistribute loans via trade credit was less pronounced later in the period.

When we restrict ourselves to the more profitable sub-sample in column 2, we see that the redistribution effect again only holds for domestic private firms, and this effect is 
much higher in the early half of the sample period than in the post-2000 period. This seems to suggest that the demand for trade credit was lower in the latter sample period, consistent with the earlier findings that the allocation of formal credit became more efficient in the latter period in Table $6 .{ }^{10}$

Because the multiple interaction terms in column 1 (of Table 9) make it difficult to assess the magnitude of the total effects of profitability and access to loans on the extension of trade credit for each ownership type, we compute $\partial$ trade credit/ $\partial$ formal credit using the coefficients from the model. For each ownership type, we compute the redistribution effect for different levels of profitability (Table 10). The effect for SOEs is positive and significant for the pooled sample. It is slightly more than $10 \%$ larger for the $10^{\text {th }}$ percentile (in ROS) SOEs than for those in the $90^{\text {th }}$ percentile, which is consistent with the result that less efficient SOEs extend more trade credit per unit of formal credit. The difference, however, is not big for the pooled sample.

The disparity becomes wider for the latter period (compare columns 2 and 3). After 2000, $\partial$ trade credit/ $\partial$ formal credit is 0.18 for SOEs that rank at the $10^{\text {th }}$ percentile in $R O S$ compared to only 0.13 for SOEs at the $90^{\text {th }}$ percentile. The significance of that derivative is also lower for SOEs at higher profitability levels in the latter period. In short, the sample split reveals that the tendency for relatively unprofitable SOEs to extend more trade credit than others has only grown stronger over time. The pattern is somewhat similar for collectives and legal-person owned firms: their redistribution effects were significant for firms at all profitability levels in the early period; in the latter one, the effect is significant only for the relatively unprofitable, and then only at the five percent level.

Private and foreign firms display somewhat different patterns than other ownership types. For the pooled sample, only highly profitable domestic private firms redistribute formal credit. From 1998 to 2000, the models imply positive credit redistribution for both types of firms, but unlike SOEs, this effect increases with profitability. For domestic private firms, the redistribution effect for the firm at the $90^{\text {th }}$ percentile (in $R O S$ ) is $75 \%$ higher than that for the firm at the $10^{\text {th }}$ percentile; for foreign firms, the corresponding figure is around 50\%. For the post-2000 period, both types of

\footnotetext{
${ }^{10}$ For collective firms, the redistribution effect in the post-2000 period is negative and decreases with profitability for both models in Table 9. This suggests that the most profitable collectives were less likely to extend trade credit than others.
} 
firms provide less trade credit when they have more formal credit, though the effect is not significant at any profitability level for either ownership type. This could indicate that as time wore on these firms faced binding credit constraints relative to their tremendous growth opportunities, and thus were less apt to extend trade credit.

It is also possible that their customers were no longer shut out of formal credit markets and thus did not need to rely on them for finance. This is also consistent with the evidence in Table 6 that the allocation of formal credit grew more rational over time. The overall pattern is consistent with the idea that trade credit, an informal financing mechanism, was gradually giving way to more formal ones. This corresponds well with the conjecture about the development of transition economies from McMillan and Woodruff (2002) that as transition goes along, formal institutions become increasingly important, even indispensable in supporting arms-length contracting. It is also telling that the redistribution effects for unprofitable SOEs grew stronger while those for private domestic, foreign, and profitable firms of all ownership types disappeared. We view this pattern as additional support for the notion that SOE trade credit was associated with substantial financial arrears and did not bring about a substantial improvement in credit allocation.

All in all, the redistribution effect from formal credit to trade credit is just slightly more than 0.15 for SOEs and is less than 0.28 for all firms in the first half of the sample period. Because some, or even much, of the redistribution from SOEs was used to cover

arrears, the 0.15 coefficient represents an upper bound on the positive effect that redistribution might have had on credit allocation. Assuming a redistribution effect of 0.2, a 100\% increase in formal credit from its mean in 1999 (0.044 from Table 4) would lead to an increase in trade credit relative to sales of 0.0088 , a $3 \%$ increase relative to the mean for trade credit in the same year. Magnitudes using other years are similar. These are therefore economically small effects. It seems unlikely that the redistribution of formal credit to trade credit was capable of sustaining the lion's share of the economic growth in China during this period.

\section{Conclusion}

Using an unusually broad sample of Chinese firms and enterprises, we find that formal credit allocation in China was biased towards relatively unprofitable SOEs and 
thus inefficient; there is evidence, however, that the allocation of formal credit improved over time. A biased and inefficient banking system may in principle give rise to the substitution of trade credit for formal credit. However, we do not find strong evidence that trade credit played an economically significant role in China. SOEs did extend more trade credit than other types of firms, though this is almost certainly due to involuntary lending by less profitable SOEs to cover financial arrears, a situation stemming in part from their low incentives to collect receivables. Profitable private firms also on-lent part of their formal credit via trade credit to support their trading partners, and the on-lending declined when the allocation of formal credit became more efficient. Trade credit might therefore have provided a substitute for loans for private firms' trading partners that were shut out of formal credit markets.

Overall, the magnitude of the on-lending was small relative to the size of the formal financial sector. In fact, the accounts receivable to sales ratio for the firms and enterprises in our sample ranges from $18 \%$ for private domestic firms to $36.5 \%$ for SOEs. It is higher than, but still comparable to, $18.5 \%$ for the U.S. Compustat firms (Petersen and Rajan, 1997, p.669), which also casts doubt on whether trade credit can account for more than a fraction of China's explosive growth. It seems likely that trade credit was but one of a vast portfolio of formal and informal arrangements that sustained Chinese growth during this period. 


\section{References}

Acemoglu, Daron and Simon Johnson, 2005. "Unbundling Institutions.” Journal of Political Economy, 113(5): 949-995.

Acemoglu, Daron, Simon Johnson, and James A. Robinson, 2001. “The Colonial Origins of Comparative Development: An Empirical Investigation.” American Economic Review, 91(5): 1369-1401.

Allen, Franklin, Jun Qian, and Meijun Qian, 2005. “Law, Finance, and Economic Growth in China.” Journal of Financial Economics, 77(1): 57-116.

Beck, Thorsten, Asli Demirguc-Kunt, and Ross Levine, 2000a. "Law, Endowments, and Finance. Journal of Financial Economics, 70(2): 137-181.

Beck, Thorsten, Asli Demirguc-Kunt, and Ross Levine, 2000a. "Law and Finance: Why Does Legal Origin Matter?” Journal of Comparative Economics, 31(4): 653-675.

Beck, Thorsten, Ross Levine, and Norman Loayza, 2000a. "Finance and the Sources of Growth,” Journal of Financial Economics, 58(1-2): 261-300.

Beck, Thorsten, Ross Levine, and Norman Loayza, 2000b. "Financial Intermediation and Growth: Causality and Causes,” Journal of Monetary Economics, 46(1): 31-77.

Biais, Bruno and Christian Gollier, 1997. “Trade Credit and Credit Rationing.” Review of Financial Studies, 10(4): 903-937.

Burkart, Mike, and Tore Ellingsen, 2004. "In-Kind Finance: A Theory of Trade Credit.” American Economic Review, 94(3): 569-590. 
Cai, Hongbin, Qiao Liu, and Geng Xiao, 2005. "Does Competition Encourage Unethical Behavior? The Case fo Profit Hiding in China.” Mimeo, University of California at Los Angeles.

Coricelli, Fabrizio, 1996. "Finance and Growth in Economies in Transition.” European Economic Review, 40: 645-653.

Cull, Robert and Lixin Colin Xu, 2003. "Who Gets Credit? The Behavior of Bureaucrats and State Banks in Allocating Credit to Chinese State-Owned Enterprises.” Journal of Development Economics, 71(2): 533-559.

Cull, Robert and Lixin Colin Xu, 2005. "Institutions, Ownership, and finance: The Determinants of Profit Reinvestment among Chinese Firms.” Journal of Financial Economics, 77(1): 117-146.

Demirguc-Kunt, Asli and Vojislav Maksimovic, 2001. "Firms as Financial Intermediaries: Evidence from Trade Credit Data.” World Bank Policy Research Working Paper No. 2696, Washington, DC.

Djankov, Simeon, Rafael La Porta, Florencio Lopez-de-Silanes, and Andre Shleifer, 2003. “Courts.” Quarterly Journal of Economics, 118(2): 453-517.

Engerman, Stanley L. and Kenneth L. Sokoloff, 2000. “Institutions, Factor Endowments, and Paths of Development in the New World.” Journal of Economic Perspectives, 14(3): 217-232.

Engerman, Stanley L. and Kenneth L. Sokoloff, 2002. "Factor Endowments, Inequality and Paths of Development among New World Economies.” Economía: Journal of the Latin American and Caribbean Economic Association, 3(1): 41-88.

Engerman, Stanley L. and Kenneth L. Sokoloff, 2005. "The Evolution of Suffrage Institutions in the New World.” Journal of Economic History, 65(4): 891-921. 
Fisman, Raymond and Inessa Love, 2003. “Trade Credit, Financial Intermediary Development, and Industry Growth.” Journal of Finance, 58(1): 353-374.

Fisman, Raymond and Mayank Raturi, 2004. "Does Competition Encourage Credit Provision? Evidence from African Trading Relationships.” Review of Economics and Statistics, 86(1): 345-52.

Ge, Ying and Jiaping Qiu, 2005. "Financial Development, Bank Discrimination and Trade Credit.” Wilfred Laurier University, Mimeo.

Huang, Yasheng. 2003. Selling China: Foreign Direct Investment During the Reform Era. Cambrige: Cambridge University Press.

Johnson, Simon, John McMillan, and Christopher Woodruff, 2002. "Property Rights and Finance.” American Economic Review, 92(5): 1335-1356.

La Porta, Rafael, Florencio Lopez-de-Silanes, Andre Shleifer, and Robert Vishny, 1998. “Law and Finance.” Journal of Political Economy, 106(6): 1113-1155.

La Porta, Rafael, Florencio Lopez-de-Silanes, Andre Shleifer and Robert Vishny, 2000. “Investor Protection and Corporate Governance." Journal of Financial Economics, 58(1-2): 3-27.

Lardy, Nicholas R., 1998. China's Unfinished Economic Revolution. Washington, DC: Brookings Institution Press.

Levine, Ross and Sara Zervos, 1998. "Stock Markets, Banks, and Economic Growth.” American Economic Review, 88(3): 537-558. 
Love, Inessa, Lorenzo A. Preve, and Virginia Sarria-Allende. 2006. “Trade Credit and Bank Credit: Evidence from Recent Financial Crises.” Journal of Financial Economics, forthcoming.

McMillan, John and Christopher Woodruff, 1999. "Interfirm Relationships and Informal Credit in Vietnam.” Quarterly Journal of Economics, 114(4): 1285-1320.

McMillan, John and Christopher Woodruff, 2002. "The Central Role of Entrepreneurs in Transitional Economices. Journal of Economic Perspectives, 16(3): 153-170.

Ng, Chee K., Janet Kiholm Smith and Richard L. Smith, 1999. "Evidence on the Determinants of Credit Terms Used in Interfirm Trade.” Journal of Finance, 54(3): 1109-1129.

Petersen, Mitchell, and Raghuram Rajan, 1997. “Trade Credit: Theories and Evidence.” Review of Financial Studies, 10(3): 661-691.

Rajan, Raghuram G. and Luigi Zingales, 1998. "Financial Dependence and Growth.” American Economic Review, 88(3): 559-586.

Smith, Janet Kiholm, 1987. “Trade Credit and Informational Asymmetry.” Journal of Finance, 42(4): 863-872. 
Table 1. Sample Characteristics

\begin{tabular}{|l|rrrrrr|}
\hline & 1998 & 1999 & 2000 & 2001 & 2002 & 2003 \\
\hline Firms in sample & 48,013 & 101,471 & 107,688 & 100,265 & 116,200 & 102868 \\
GDP of China (Billions Yuan) & 7835 & 8207 & 8947 & 9731 & 10479 & 11728 \\
\% GDP accounted for by sample & 11.1 & 20.3 & 21.7 & 20.8 & 24.6 & 25.2 \\
\% industrial value added accounted by sample & 26.1 & 47.4 & 49.6 & 47.8 & 55.6 & 47.3 \\
\hline
\end{tabular}


Table 2. Evolution of Ownership over Time: Share of firms in Sample, By Ownership type

\begin{tabular}{lccccc}
\hline Year & State & Collective & $\begin{array}{c}\text { Legal- } \\
\text { person }\end{array}$ & Domestic private & Foreign \\
1998 & 0.329 & 0.285 & 0.132 & 0.131 & 0.124 \\
1999 & 0.303 & 0.268 & 0.149 & 0.151 & 0.128 \\
2000 & 0.256 & 0.236 & 0.172 & 0.202 & 0.133 \\
2001 & 0.203 & 0.192 & 0.187 & 0.274 & 0.144 \\
2002 & 0.185 & 0.168 & 0.191 & 0.306 & 0.150 \\
2003 & 0.162 & 0.130 & 0.209 & 0.339 & 0.159 \\
\hline
\end{tabular}


Table 3. Sample Characteristics, By Type of Owner

\begin{tabular}{lccccc}
\hline & State-Owned & Collective & Legal-Person & Domestic Private & Foreign \\
Formal finance (i.e., & 0.062 & 0.029 & 0.032 & 0.022 & 0.019 \\
BANK): interest & $(0.093)$ & $(0.047)$ & $(0.056)$ & $(0.033)$ & $(0.042)$ \\
paid/sales & & & & & \\
Trade credit: accounts & 0.365 & 0.210 & 0.228 & 0.180 & 0.224 \\
receivable/sales & $(0.475)$ & $(0.298)$ & $(0.318)$ & $(0.236)$ & $(0.298)$ \\
Return on sales (ROS) & -0.005 & 0.132 & 0.117 & 0.135 & 0.089 \\
& $(0.396)$ & $(0.243)$ & $(0.266)$ & $(0.195)$ & $(0.243)$ \\
Sales (million yuan) & 85.626 & 34.826 & 84.391 & 36.830 & 104.785 \\
& $(642.851)$ & $(138.350)$ & $(596.956)$ & $(133.474)$ & $(559.121)$ \\
Number of employees & 735.273 & 278.922 & 384.549 & 236.507 & 378.297 \\
& $(3043.598)$ & $(622.811)$ & $(1167.907)$ & $(448.009)$ & $(739.415)$ \\
Firm age (year) & 26.087 & 14.803 & 12.023 & 10.595 & 6.729 \\
& $(17.086)$ & $(12.073)$ & $(13.851)$ & $(11.191)$ & $(4.516)$ \\
Herfindahl Index for & 0.306 & 0.228 & 0.280 & 0.209 & 0.263 \\
top 10 firms of the & $(2.443)$ & $(1.858)$ & $(2.146)$ & $(1.723)$ & $(2.011)$ \\
industry (*100) & & & & & \\
\hline
\end{tabular}

Standard deviations in parentheses. 
Table 4. Variation in Key Variables over Time

\begin{tabular}{lcccccc}
\hline & \multicolumn{2}{c}{ ROS } & \multicolumn{2}{c}{ Access to formal credit } & \multicolumn{2}{c}{ Trade credit } \\
year & Mean & Std. & Mean & Std. & Mean & Std. \\
1998 & 0.064 & 0.322 & 0.053 & 0.078 & 0.258 & 0.348 \\
1999 & 0.076 & 0.313 & 0.044 & 0.072 & 0.272 & 0.373 \\
2000 & 0.088 & 0.293 & 0.035 & 0.061 & 0.260 & 0.370 \\
2001 & 0.100 & 0.275 & 0.029 & 0.054 & 0.236 & 0.345 \\
2002 & 0.107 & 0.269 & 0.026 & 0.050 & 0.230 & 0.332 \\
2003 & 0.112 & 0.251 & 0.023 & 0.046 & 0.215 & 0.308 \\
\hline
\end{tabular}


Table 5. Correlation of Between Formal Finance Received and Trade Credit Extended: By Ownership Type

\begin{tabular}{lc}
\hline Ownership & Correlation Coefficient \\
SOEs & 0.3054 \\
& $(0.0000)$ \\
Collective & 0.2765 \\
& $(0.0000)$ \\
Legal-Person & 0.3390 \\
& $(0.0000)$ \\
Private & 0.2838 \\
& $(0.0000)$ \\
Foreign & 0.1828 \\
& $(0.0000)$ \\
\hline
\end{tabular}

Note. In parentheses are p-values. 
Table 6. Determinants of Access to Formal Finance

\begin{tabular}{|c|c|c|c|c|c|c|}
\hline & $\begin{array}{l}\text { (1) } \\
\text { full sample }\end{array}$ & $\begin{array}{l}\text { (2) } \\
\text { profitable } \\
\text { sample }\end{array}$ & $\begin{array}{l}\text { (3) } \\
\text { full sample }\end{array}$ & $\begin{array}{l}(4) \\
\text { profitable } \\
\text { sample }\end{array}$ & $\begin{array}{l}\text { (5) } \\
\text { full sample }\end{array}$ & $\begin{array}{l}\text { (6) } \\
\text { profitable } \\
\text { sample }\end{array}$ \\
\hline Collective & $\begin{array}{l}-0.006 \\
(10.77)^{* *}\end{array}$ & $\begin{array}{l}-0.003 \\
(4.12)^{* *}\end{array}$ & $\begin{array}{l}-0.006 \\
(10.85)^{* *}\end{array}$ & $\begin{array}{l}-0.003 \\
(3.17)^{* *}\end{array}$ & $\begin{array}{l}-0.006 \\
(10.65)^{* *}\end{array}$ & $\begin{array}{l}-0.003 \\
(3.10)^{* *}\end{array}$ \\
\hline Legal-Person & $\begin{array}{l}-0.006 \\
(11.24)^{* *}\end{array}$ & $\begin{array}{l}-0.003 \\
(4.80)^{* *}\end{array}$ & $\begin{array}{l}-0.006 \\
(11.53)^{* *}\end{array}$ & $\begin{array}{l}-0.003 \\
(3.59)^{* *}\end{array}$ & $\begin{array}{l}-0.006 \\
(11.22)^{* *}\end{array}$ & $\begin{array}{l}-0.003 \\
(3.79)^{* *}\end{array}$ \\
\hline Domestic Private & $\begin{array}{l}-0.007 \\
(13.37)^{* *}\end{array}$ & $\begin{array}{l}-0.003 \\
(5.34)^{* *}\end{array}$ & $\begin{array}{l}-0.008 \\
(14.94)^{* *}\end{array}$ & $\begin{array}{l}-0.003 \\
(3.59)^{* *}\end{array}$ & $\begin{array}{l}-0.008 \\
(14.39)^{* *}\end{array}$ & $\begin{array}{l}-0.003 \\
(3.83)^{* *}\end{array}$ \\
\hline Foreign & $\begin{array}{l}-0.007 \\
(10.61)^{* *}\end{array}$ & $\begin{array}{l}-0.004 \\
(5.56)^{* *}\end{array}$ & $\begin{array}{l}-0.007 \\
(10.45)^{* *}\end{array}$ & $\begin{array}{l}-0.004 \\
(4.46)^{* *}\end{array}$ & $\begin{array}{l}-0.007 \\
(10.47)^{* *}\end{array}$ & $\begin{array}{l}-0.005 \\
(4.74)^{* *}\end{array}$ \\
\hline $\ln \left(\right.$ Sales $\left._{t-1}\right)$ & $\begin{array}{l}-0.000 \\
(1.58)\end{array}$ & $\begin{array}{l}0.000 \\
(0.16)\end{array}$ & $\begin{array}{l}-0.000 \\
(1.20)\end{array}$ & $\begin{array}{l}0.000 \\
(0.17)\end{array}$ & $\begin{array}{l}-0.001 \\
(2.33)^{*}\end{array}$ & $\begin{array}{l}-0.000 \\
(0.05)\end{array}$ \\
\hline $\ln$ (firm age) & $\begin{array}{l}0.002 \\
(9.53)^{* *}\end{array}$ & $\begin{array}{l}0.001 \\
(4.82)^{* *}\end{array}$ & $\begin{array}{l}0.002 \\
(9.46)^{* *}\end{array}$ & $\begin{array}{l}0.001 \\
(4.81)^{* *}\end{array}$ & $\begin{array}{l}0.002 \\
(9.08)^{* *}\end{array}$ & $\begin{array}{l}0.001 \\
(4.53)^{* *}\end{array}$ \\
\hline Herfindahl & $\begin{array}{l}0.004 \\
(0.74)\end{array}$ & $\begin{array}{l}0.000 \\
(0.10)\end{array}$ & $\begin{array}{l}0.004 \\
(0.69)\end{array}$ & $\begin{array}{l}0.001 \\
(0.10)\end{array}$ & $\begin{array}{l}0.004 \\
(0.69)\end{array}$ & $\begin{array}{l}0.001 \\
(0.12)\end{array}$ \\
\hline$R O S_{t-1}$ & $\begin{array}{l}-0.008 \\
(14.10)^{* *}\end{array}$ & $\begin{array}{l}-0.001 \\
(1.86)\end{array}$ & & & & \\
\hline $\operatorname{ROS}_{t-1} *$ State & & & $\begin{array}{l}-0.016 \\
(13.69)^{* *}\end{array}$ & $\begin{array}{l}-0.001 \\
(0.70)\end{array}$ & $\begin{array}{l}-0.022 \\
(15.60)^{* *}\end{array}$ & $\begin{array}{l}0.002 \\
(1.07)\end{array}$ \\
\hline $\operatorname{ROS}_{t-1} *$ Collective & & & $\begin{array}{l}-0.005 \\
(4.58)^{* *}\end{array}$ & $\begin{array}{l}-0.001 \\
(0.65)\end{array}$ & $\begin{array}{l}-0.010 \\
(8.07)^{* *}\end{array}$ & $\begin{array}{l}0.001 \\
(0.93)\end{array}$ \\
\hline $\operatorname{ROS}_{t-1} *$ Legal-person & & & $\begin{array}{l}-0.004 \\
(2.88)^{* *}\end{array}$ & $\begin{array}{l}-0.001 \\
(0.74)\end{array}$ & $\begin{array}{l}-0.011 \\
(6.57)^{* *}\end{array}$ & $\begin{array}{l}0.001 \\
(0.54)\end{array}$ \\
\hline$R O S_{t-1} *$ Domestic private & & & $\begin{array}{l}0.002 \\
(1.61)\end{array}$ & $\begin{array}{l}-0.003 \\
(1.90)\end{array}$ & $\begin{array}{l}-0.005 \\
(3.74)^{* *}\end{array}$ & $\begin{array}{l}0.002 \\
(1.12)\end{array}$ \\
\hline $\operatorname{ROS}_{t-1} *$ Foreign & & & $\begin{array}{l}-0.007 \\
(5.32)^{* *}\end{array}$ & $\begin{array}{l}-0.001 \\
(0.75)\end{array}$ & $\begin{array}{l}-0.017 \\
(9.72)^{* *}\end{array}$ & $\begin{array}{l}-0.001 \\
(0.44)\end{array}$ \\
\hline$R O S_{t-1} *$ State * post-2000 & & & & & $\begin{array}{l}0.013 \\
(7.73)^{* *}\end{array}$ & $\begin{array}{l}-0.007 \\
(3.63)^{* *}\end{array}$ \\
\hline$R O S_{t-1} *$ Collective* post-2000 & & & & & $\begin{array}{l}0.010 \\
(7.32)^{* *}\end{array}$ & $\begin{array}{l}-0.005 \\
(2.97)^{* *}\end{array}$ \\
\hline $\operatorname{ROS}_{t-1} *$ Legal-person* post-2000 & & & & & $\begin{array}{l}0.012 \\
(6.38)^{* *}\end{array}$ & $\begin{array}{l}-0.003 \\
(1.81)\end{array}$ \\
\hline$R O S_{t-1} *$ Domestic private*post-2000 & & & & & $\begin{array}{l}0.010 \\
(6.77)^{* *}\end{array}$ & $\begin{array}{l}-0.007 \\
(3.90)^{* *}\end{array}$ \\
\hline $\operatorname{ROS}_{t-1} *$ Foreign* post-2000 & & & & & $\begin{array}{l}0.017 \\
(8.52)^{* *}\end{array}$ & $\begin{array}{l}-0.001 \\
(0.34)\end{array}$ \\
\hline Observations & 477702 & 236747 & 477702 & 236747 & 477702 & 236747 \\
\hline R-squared & 0.76 & 0.78 & 0.77 & 0.78 & 0.77 & 0.78 \\
\hline
\end{tabular}

The dependent variable is interest payments over sales.

All models include firm fixed effects.

Profitable sub-sample refers to those firm-years in which $\operatorname{ROS}_{t-1}>$ median ROS (10.1\%).

* and ** represent statistical significance at the 5 and 1 percent levels.

Standard errors are White-corrected.

Year dummies are also controlled for, and their coefficients are not reported. 
Table 7. Trade Credit, Profitability and Formal Finance

\begin{tabular}{|c|c|c|c|c|}
\hline & $\begin{array}{l}\text { (1) } \\
\text { full sample }\end{array}$ & $\begin{array}{l}(2) \\
\text { profitable } \\
\text { sample }\end{array}$ & $\begin{array}{l}\text { (3) } \\
\text { full sample }\end{array}$ & $\begin{array}{l}\text { (4) } \\
\text { profitable } \\
\text { sample }\end{array}$ \\
\hline \multirow[t]{2}{*}{ Collective } & -0.022 & -0.019 & -0.024 & -0.019 \\
\hline & $(6.40)^{* *}$ & $(3.42)^{* *}$ & $(6.79)^{* *}$ & $(3.44)^{* *}$ \\
\hline \multirow[t]{2}{*}{ Legal-Person } & -0.029 & -0.024 & -0.031 & -0.023 \\
\hline & $(8.90)^{* *}$ & $(4.20)^{* *}$ & $(9.08)^{* *}$ & $(4.17)^{* *}$ \\
\hline \multirow[t]{2}{*}{ Domestic Private } & -0.033 & -0.031 & -0.037 & -0.031 \\
\hline & $(9.75)^{* *}$ & $(5.39)^{* *}$ & $(10.72)^{* *}$ & $(5.45)^{* *}$ \\
\hline \multirow[t]{2}{*}{ Foreign } & -0.020 & -0.013 & -0.022 & -0.012 \\
\hline & $(4.58)^{* *}$ & $(1.94)$ & $(5.04)^{* *}$ & $(1.78)$ \\
\hline \multirow[t]{2}{*}{$\ln \left(\right.$ Sales $\left._{t-1}\right)$} & -0.010 & -0.005 & -0.009 & -0.005 \\
\hline & $(6.85)^{* *}$ & $(2.16)^{*}$ & $(6.63)^{* *}$ & $(2.17)^{*}$ \\
\hline \multirow[t]{2}{*}{ ln(firm age) } & 0.018 & 0.014 & 0.018 & 0.014 \\
\hline & $(15.33)^{* *}$ & $(8.08)^{* *}$ & $(15.24)^{* *}$ & $(8.08)^{* *}$ \\
\hline \multirow[t]{2}{*}{ Herfindahl } & 0.017 & -0.003 & 0.017 & -0.003 \\
\hline & $(0.55)$ & $(0.05)$ & $(0.53)$ & $(0.05)$ \\
\hline \multirow[t]{2}{*}{$R O S_{t-1}$} & -0.022 & -0.024 & -0.025 & -0.021 \\
\hline & $(6.95)^{* *}$ & $(4.56)^{* *}$ & $(7.42)^{* *}$ & $(3.35)^{* *}$ \\
\hline \multirow[t]{2}{*}{$B A N K_{t-1} *$ State } & 0.178 & 0.100 & 0.152 & 0.147 \\
\hline & $(6.22)^{* *}$ & $(1.13)$ & $(4.53)^{* *}$ & $(1.27)$ \\
\hline \multirow[t]{2}{*}{$B A N K_{t-1} *$ Collective } & 0.125 & 0.185 & 0.148 & 0.269 \\
\hline & $(3.30)^{* *}$ & $(2.53)^{*}$ & $(3.86)^{* *}$ & $(2.78)^{* *}$ \\
\hline \multirow[t]{2}{*}{$B A N K_{t-1} *$ Legal-Person } & 0.139 & 0.100 & 0.143 & 0.118 \\
\hline & $(3.37)^{* *}$ & $(0.99)$ & $(3.51)^{* *}$ & $(0.99)$ \\
\hline \multirow[t]{2}{*}{$B A N K_{t-1} *$ Domestic private } & -0.062 & 0.256 & 0.034 & 0.348 \\
\hline & $(1.33)$ & $(2.61)^{* *}$ & $(0.71)$ & $(2.96)^{* *}$ \\
\hline \multirow[t]{2}{*}{$B A N K_{t-1} *$ Foreign } & 0.067 & 0.013 & 0.111 & -0.098 \\
\hline & $(1.07)$ & $(0.07)$ & $(1.58)$ & $(0.44)$ \\
\hline \multirow[t]{2}{*}{$B A N K_{t-1} * R O S_{t-1} *$ State } & & & -0.032 & -0.077 \\
\hline & & & $(0.84)$ & $(0.44)$ \\
\hline \multirow[t]{2}{*}{$B A N K_{t-1} * R O S_{t-1} *$ Collective } & & & 0.103 & -0.164 \\
\hline & & & $(1.61)$ & $(0.87)$ \\
\hline \multirow[t]{2}{*}{$B A N K_{t-1} * R O S_{t-1} *$ Legal-Person } & & & 0.007 & -0.031 \\
\hline & & & $(0.11)$ & $(0.13)$ \\
\hline \multirow[t]{2}{*}{$B A N K_{t-1} * R O S_{t-1} *$ Domestic private } & & & 0.452 & -0.190 \\
\hline & & & $(4.74)^{* *}$ & $(0.70)$ \\
\hline \multirow[t]{2}{*}{$B A N K_{t-1} * R O S_{t-1} *$ Foreign } & & & 0.104 & 0.238 \\
\hline & & & (1.15) & $(0.71)$ \\
\hline Observations & 476810 & 235587 & 476810 & 235587 \\
\hline R-squared & 0.76 & 0.80 & 0.76 & 0.80 \\
\hline
\end{tabular}

The dependent variable is accounts receivable over sales.

All models include firm fixed effects.

Profitable sub-sample refers to those firm-years in which $R O S_{t-1}>$ median ROS (10.1\%).

* and ** represent statistical significance at the 5 and 1 percent levels.

Standard errors are White-corrected.

Year dummies are also controlled for, and their coefficients are not reported. 
Table 8. Tests for Reverse Causality

Dependent variable $=$ Formal Finance Access

\begin{tabular}{|c|c|c|c|c|}
\hline & (1) & (2) & (3) & (4) \\
\hline & full sample & profitable sample & full sample & profitable sample \\
\hline Collecitve & $\begin{array}{l}-0.005 \\
(10.57)^{* *}\end{array}$ & $\begin{array}{l}-0.003 \\
(4.01)^{* *}\end{array}$ & $\begin{array}{l}-0.004 \\
(6.47)^{* *}\end{array}$ & $\begin{array}{l}-0.003 \\
(3.78)^{* *}\end{array}$ \\
\hline Legal-person & $\begin{array}{l}-0.006 \\
(11.07)^{* *}\end{array}$ & $\begin{array}{l}-0.003 \\
(4.67)^{* *}\end{array}$ & $\begin{array}{l}-0.004 \\
(6.54)^{* *}\end{array}$ & $\begin{array}{l}-0.003 \\
(3.83)^{* *}\end{array}$ \\
\hline Citizen & $\begin{array}{l}-0.007 \\
(13.13)^{* *}\end{array}$ & $\begin{array}{l}-0.003 \\
(5.17)^{* *}\end{array}$ & $\begin{array}{l}-0.004 \\
(7.19)^{* *}\end{array}$ & $\begin{array}{l}-0.003 \\
(4.40)^{* *}\end{array}$ \\
\hline Foreign & $\begin{array}{l}-0.007 \\
(10.42)^{* *}\end{array}$ & $\begin{array}{l}-0.004 \\
(5.47)^{* *}\end{array}$ & $\begin{array}{l}-0.005 \\
(7.76)^{* *}\end{array}$ & $\begin{array}{l}-0.005 \\
(5.05)^{* *}\end{array}$ \\
\hline $\ln \left(\right.$ Sales $\left._{t-1}\right)$ & $\begin{array}{l}0.000 \\
(1.96)\end{array}$ & $\begin{array}{l}0.001 \\
(1.95)\end{array}$ & $\begin{array}{l}0.000 \\
(1.75)\end{array}$ & $\begin{array}{l}0.001 \\
(1.95)\end{array}$ \\
\hline $\ln$ (firm age) & $\begin{array}{l}0.002 \\
(9.32)^{* *}\end{array}$ & $\begin{array}{l}0.001 \\
(4.72)^{* *}\end{array}$ & $\begin{array}{l}0.002 \\
(9.29)^{* *}\end{array}$ & $\begin{array}{l}0.001 \\
(4.71)^{* *}\end{array}$ \\
\hline Herfindahl & $\begin{array}{l}0.004 \\
(0.71)\end{array}$ & $\begin{array}{l}0.001 \\
(0.19)\end{array}$ & $\begin{array}{l}0.004 \\
(0.68)\end{array}$ & $\begin{array}{l}0.001 \\
(0.18)\end{array}$ \\
\hline$R O S_{t-1}$ & $\begin{array}{l}-0.008 \\
(13.73)^{* *}\end{array}$ & $\begin{array}{l}-0.002 \\
(2.18)^{*}\end{array}$ & $\begin{array}{l}-0.008 \\
(13.60)^{* *}\end{array}$ & $\begin{array}{l}-0.002 \\
(2.19)^{*}\end{array}$ \\
\hline Trade Credit $_{t-1}$ & $\begin{array}{l}0.005 \\
(6.95)^{* *}\end{array}$ & $\begin{array}{l}0.004 \\
(3.53)^{* *}\end{array}$ & & \\
\hline Trade Credit $_{t-1}{ }^{*}$ state & & & $\begin{array}{l}0.008 \\
(6.85)^{* *}\end{array}$ & $\begin{array}{l}0.003 \\
(1.51)\end{array}$ \\
\hline Trade Credit $_{t-1} *$ collective & & & $\begin{array}{l}0.003 \\
(2.69)^{* *}\end{array}$ & $\begin{array}{l}0.005 \\
(3.16)^{* *}\end{array}$ \\
\hline Trade Credit $_{t-1} *$ legal-person & & & $\begin{array}{l}0.003 \\
(2.36)^{*}\end{array}$ & $\begin{array}{l}0.003 \\
(1.78)\end{array}$ \\
\hline Trade Credit $_{t-1} *$ domestic private & & & $\begin{array}{l}-0.001 \\
(1.08)\end{array}$ & $\begin{array}{l}0.003 \\
(1.94)\end{array}$ \\
\hline Trade Credit $_{t-1} *$ foreign & & & $\begin{array}{l}0.005 \\
(3.61)^{* *}\end{array}$ & $\begin{array}{l}0.004 \\
(2.23)^{*}\end{array}$ \\
\hline Observations & 475274 & 235734 & 475274 & 235734 \\
\hline R-squared & 0.77 & 0.78 & 0.77 & 0.78 \\
\hline
\end{tabular}

All models include firm fixed effects.

Profitable sub-sample refers to those firm-years in which $\operatorname{ROS}_{t-1}>$ median ROS (10.1\%).

* and ** represent statistical significance at the 5 and 1 percent levels.

Standard errors are White-corrected.

Year dummies are also controlled for, and their coefficients are not reported. 
Table 9. Trade Credit, Profitability and Formal Finance: By Periods

(1) full sample

\begin{tabular}{|c|c|c|}
\hline Collective & $\begin{array}{c}-0.023 \\
(6.59)^{* *}\end{array}$ & $\begin{array}{c}-0.019 \\
(3.41)^{* *}\end{array}$ \\
\hline Legal-Person & $\begin{array}{c}-0.030 \\
(8.94)^{* *}\end{array}$ & $\begin{array}{c}-0.024 \\
(4.21)^{* *}\end{array}$ \\
\hline Domestic Private & $\begin{array}{c}-0.036 \\
(10.41)^{* *}\end{array}$ & $\begin{array}{c}-0.031 \\
(5.46)^{* *}\end{array}$ \\
\hline Foreign & $\begin{array}{c}-0.020 \\
(4.60)^{* *}\end{array}$ & $\begin{array}{l}-0.011 \\
(1.61)\end{array}$ \\
\hline$R O S_{t-1}$ & $\begin{array}{c}-0.025 \\
(7.31)^{* *}\end{array}$ & $\begin{array}{c}-0.021 \\
(3.35)^{* *}\end{array}$ \\
\hline$B A N K_{t-1} *$ State & $\begin{array}{c}0.156 \\
(4.64)^{* *}\end{array}$ & $\begin{array}{l}0.166 \\
(1.30)\end{array}$ \\
\hline$B A N K_{t-1} *$ State $^{*}$ post-2000 & $\begin{array}{l}-0.005 \\
(0.13) \\
\end{array}$ & $\begin{array}{l}-0.076 \\
(0.49) \\
\end{array}$ \\
\hline$B A N K_{t-1} *$ Collective & $\begin{array}{c}0.151 \\
(4.01)^{* *}\end{array}$ & $\begin{array}{l}0.190 \\
(1.87)\end{array}$ \\
\hline$B A N K_{t-1}{ }^{*}$ Collective* post-2000 & $\begin{array}{l}-0.012 \\
(0.24)\end{array}$ & $\begin{array}{l}0.195 \\
(1.36)\end{array}$ \\
\hline$B A N K_{t-1} *$ Legal-Person & $\begin{array}{c}0.171 \\
(3.88)^{* *}\end{array}$ & $\begin{array}{l}0.121 \\
(0.88)\end{array}$ \\
\hline$B A N K_{t-1} *$ Legal * post-2000 & $\begin{array}{l}-0.065 \\
(1.24) \\
\end{array}$ & $\begin{array}{l}-0.018 \\
(0.10) \\
\end{array}$ \\
\hline$B A N K_{t-1} *$ Domestic private & $\begin{array}{c}0.170 \\
(3.56)^{* *}\end{array}$ & $\begin{array}{c}0.548 \\
(3.89)^{* *}\end{array}$ \\
\hline$B A N K_{t-1} *$ Domestic private * post-2000 & $\begin{array}{c}-0.256 \\
(4.59) * *\end{array}$ & $\begin{array}{l}-0.338 \\
(2.02)^{*}\end{array}$ \\
\hline$B A N K_{t-1}$ *Foreign & $\begin{array}{c}0.218 \\
(3.07)^{* *}\end{array}$ & $\begin{array}{l}0.052 \\
(0.21)\end{array}$ \\
\hline$B A N K_{t-1} *_{\text {Foreign }} *$ Post-2000 & $\begin{array}{c}-0.293 \\
(3.44)^{* *}\end{array}$ & $\begin{array}{l}-0.363 \\
(1.09) \\
\end{array}$ \\
\hline$B A N K_{t-1} * R O S_{t-1} *$ State & $\begin{array}{l}-0.009 \\
(0.21)\end{array}$ & $\begin{array}{l}-0.035 \\
(0.18)\end{array}$ \\
\hline$B A N K_{t-1} * R O S_{t-1} *$ State * post-2000 & $\begin{array}{l}-0.055 \\
(0.95) \\
\end{array}$ & $\begin{array}{l}-0.080 \\
(0.26) \\
\end{array}$ \\
\hline$B A N K_{t-1} * R O S_{t-1} *$ Collective & $\begin{array}{c}0.221 \\
(3.43)^{* *}\end{array}$ & $\begin{array}{l}0.126 \\
(0.68)\end{array}$ \\
\hline$B A N K_{t-1} * R O S_{t-1} *$ Collective *post-2000 & $\begin{array}{c}-0.316 \\
(2.63) * * \\
\end{array}$ & $\begin{array}{l}-0.741 \\
(2.08)^{*} \\
\end{array}$ \\
\hline$B A N K_{t-1} * R O S_{t-1} *$ Legal-Person & $\begin{array}{l}0.025 \\
(0.34)\end{array}$ & $\begin{array}{l}0.107 \\
(0.32)\end{array}$ \\
\hline$B A N K_{t-1} * R O S_{t-1} *$ Legal * post-2000 & $\begin{array}{l}-0.041 \\
(0.40) \\
\end{array}$ & $\begin{array}{l}-0.268 \\
(0.58) \\
\end{array}$ \\
\hline$B A N K_{t-1} * R O S_{t-1} *$ Domestic private & $\begin{array}{c}0.354 \\
(3.29)^{* *}\end{array}$ & $\begin{array}{l}-0.340 \\
(1.05)\end{array}$ \\
\hline$B A N K_{t-1} * R O S_{t-1} *$ D. private $*$ post-2000 & $\begin{array}{l}0.135 \\
(0.89)\end{array}$ & $\begin{array}{l}0.225 \\
(0.50) \\
\end{array}$ \\
\hline
\end{tabular}




\begin{tabular}{lcc}
\hline$B A N K_{t-1} * R O S_{t-1} *$ Foreign & 0.196 & 0.350 \\
& $(2.06)^{*}$ & $(0.68)$ \\
$B A N K_{t-1} * R O S_{t-1} *$ Foreign * post-2000 & -0.226 & -0.275 \\
& $(1.37)$ & $(0.36)$ \\
\hline Observations & 476810 & 235587 \\
R-squared & 0.76 & 0.80 \\
\hline
\end{tabular}

The dependent variable is accounts receivable over sales.

All models include firm fixed effects.

Other controls (unreported) are log firm size, log firm age, the Herfindahl index, and year dummies.

Their coefficients are not reported.

Profitable sub-sample refers to those firm-years in which $\operatorname{ROS}_{t-1}>$ median ROS (10.1\%).

* and ** represent statistical significance at the 5 and 1 percent levels.

Standard errors are White-corrected. 
Table 10. The Implied Redistribution Effect from Formal Credit to Trade Credit

\begin{tabular}{|c|c|c|c|c|}
\hline & $\begin{array}{l}\text { ROS percentiles } \\
\text { (from less to } \\
\text { more profitable) }\end{array}$ & 1998-2003 & $1998-2000$ & post-2000 \\
\hline \multirow[t]{3}{*}{ State-Owned } & $10 \%$ & $\begin{array}{l}0.165 \\
(0.028)^{* *}\end{array}$ & $\begin{array}{l}0.160 \\
(0.029) * *\end{array}$ & $\begin{array}{l}0.176 \\
(0.038) * *\end{array}$ \\
\hline & $50 \%$ & $\begin{array}{l}0.151 \\
(0.034)^{* *}\end{array}$ & $\begin{array}{l}0.156 \\
(0.034)^{* *}\end{array}$ & $\begin{array}{l}0.148 \\
(0.048) * *\end{array}$ \\
\hline & $90 \%$ & $\begin{array}{l}0.141 \\
(0.041)^{* *}\end{array}$ & $\begin{array}{l}0.153 \\
(0.042)^{* *}\end{array}$ & $\begin{array}{l}0.129 \\
(0.060)^{*}\end{array}$ \\
\hline \multirow[t]{3}{*}{ Collective } & $10 \%$ & $\begin{array}{l}0.140 \\
(0.038) * *\end{array}$ & $\begin{array}{l}0.132 \\
(0.037)^{* *}\end{array}$ & $\begin{array}{l}0.146 \\
(0.057)^{*}\end{array}$ \\
\hline & $50 \%$ & $\begin{array}{l}0.160 \\
(0.041)^{* *}\end{array}$ & $\begin{array}{l}0.177 \\
(0.040)^{* *}\end{array}$ & $\begin{array}{l}0.128 \\
(0.063)^{*}\end{array}$ \\
\hline & $90 \%$ & $\begin{array}{l}0.183 \\
(0.048)^{* *}\end{array}$ & $\begin{array}{l}0.225 \\
(0.047)^{* *}\end{array}$ & $\begin{array}{l}0.107 \\
(0.076)\end{array}$ \\
\hline \multirow[t]{3}{*}{ Legal-Person } & $10 \%$ & $\begin{array}{l}0.142 \\
(0.039)^{* *}\end{array}$ & $\begin{array}{l}0.168 \\
(0.041)^{* *}\end{array}$ & $\begin{array}{l}0.110 \\
(0.051)^{*}\end{array}$ \\
\hline & $50 \%$ & $\begin{array}{l}0.144 \\
(0.044)^{* *}\end{array}$ & $\begin{array}{l}0.173 \\
(0.048)^{* *}\end{array}$ & $\begin{array}{l}0.107 \\
(0.057)\end{array}$ \\
\hline & $90 \%$ & $\begin{array}{l}0.145 \\
(0.052)^{* *}\end{array}$ & $\begin{array}{l}0.179 \\
(0.058) * *\end{array}$ & $\begin{array}{l}0.103 \\
(0.069)\end{array}$ \\
\hline \multirow[t]{3}{*}{ Domestic private } & $10 \%$ & $\begin{array}{l}0.019 \\
(0.046)\end{array}$ & $\begin{array}{l}0.159 \\
(0.047)^{* *}\end{array}$ & $\begin{array}{l}-0.100 \\
(0.059)\end{array}$ \\
\hline & $50 \%$ & $\begin{array}{l}0.084 \\
(0.051)\end{array}$ & $\begin{array}{l}0.210 \\
(0.052)^{* *}\end{array}$ & $\begin{array}{l}-0.029 \\
(0.064)\end{array}$ \\
\hline & $90 \%$ & $\begin{array}{l}0.171 \\
(0.061)^{* *}\end{array}$ & $\begin{array}{l}0.278 \\
(0.064)^{* *}\end{array}$ & $\begin{array}{l}0.065 \\
(0.076)\end{array}$ \\
\hline \multirow[t]{3}{*}{ Foreign } & $10 \%$ & $\begin{array}{l}0.097 \\
(0.065)\end{array}$ & $\begin{array}{l}0.186 \\
(0.064)^{* *}\end{array}$ & $\begin{array}{l}-0.077 \\
(0.091)\end{array}$ \\
\hline & $50 \%$ & $\begin{array}{l}0.121 \\
(0.075)\end{array}$ & $\begin{array}{l}0.229 \\
(0.076)^{* *}\end{array}$ & $\begin{array}{l}-0.086 \\
(0.103)\end{array}$ \\
\hline & $90 \%$ & $\begin{array}{l}0.143 \\
(0.087)\end{array}$ & $\begin{array}{l}0.269 \\
(0.091)^{* *}\end{array}$ & $\begin{array}{l}-0.094 \\
(0.123)\end{array}$ \\
\hline
\end{tabular}

Standard errors in parentheses. The results are based on regressions in Tables 7 and 9. 